Article

\title{
When Water Turns Deadly: Investigating Source Identification and Quality of Drinking Water in Piwoyi Community of Fed- eral Capital Territory, Abuja Nigeria
}

\author{
Afolabi Abiodun Segun 1, Raimi Morufu Olalekan 2,* \\ ${ }^{1}$ Department of Geography, Faculty of Natural Science, Ibrahim Badamasi Babangida University, Lapai, Niger \\ State, Nigeria. \\ ${ }^{2}$ Department of Community Medicine, Environmental Health Unit, Faculty of Clinical Sciences, Niger Delta \\ University, Wilberforce Island, Bayelsa State, Nigeria. \\ *Correspondence: morufuolalekan.raimi@gmail.com; olamuf001@outlook.com; sorfina2012@live.com
}

How to cite this paper: Segun, A. A., \& Raimi, M. O. (2021). When Water Turns Deadly: Investigating Source Identification and Quality of Drinking Water in Piwoyi Community of Fed-eral Capital Territory, Abuja Nigeria. Online Journal of Chemistry,

1(1). Retrieved from

https://www.scipublica-

tions.com/journal/index.php/ojc/article/view/87

Received: July 8, 2021

Accepted: August 15, 2021

Published: August 16, 2021

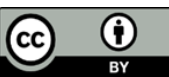

Copyright: () 2021 by the authors. Submitted for possible open access publication under the terms and conditions of the Creative Commons Attribution (CC BY) license (http://creativecommons.org/licenses/by/4.0/).

\begin{abstract}
Essentiality of water sustain life, and a satisfactory supply must be readily available to promote health, prolong life expectancy and prevent diseases. This study assesses the sources and quality of drinking water in Piwoyi community of Federal Capital Territory, Abuja, Nigeria. Thirtyfive (35) Boreholes and Two (2) Sachet water were identified sources of drinking water in Piwoyi Community. Six Samples (5 Boreholes and 1Sachet water) were selected at random and analyzed in the laboratory. The Physicochemical parameters examined include electrical conductivity (EC), pH, temperature, turbidity, dissolve oxygen (DO), chloride, total hardness, alkalinity, nitrate, calcium, magnesium, phosphate, phosphorous, sulphate, sodium, potassium, fluoride, bicarbonate, nitratenitrogen, nitrite, copper, iron and zinc; and Microbiological parameters include Coliforms, E-coli and Faecal Strep. The results of analysis shows significant concentration of physicochemical and microbiological parameters in the samples of water analyzed according to Nigerian Standard for Drinking Water Quality thereby makes the water unsafe for drinking. Drinking from these sources of water will pose serious health risk to the people of Piwoyi Community. Therefore, the study helps to identify the contaminated locations as well as assist to follow emerging remedial measures toward controlling the contamination source in the community. It also recommends continuous monitoring and enforcement of environmental violations, aggressive sensitization on water sanitation and hygiene; adequate purification of water at domestic level; and government support on potable water supply and establish reasonable management strategies for sustainable water quality protection toward protecting public health.
\end{abstract}

Keywords: Emerging Remedial Measures; Health Risk Assessment; Drinking Water Resources, Piwoyi Community, Federal Capital Territory, Nigeria

\section{Introduction}

Some current studies on water quality in Nigeria comprise: Assessment of Trace Elements in Surface and Ground Water Quality by Morufu Raimi and Clinton Ezekwe [1]; Water-Related Problems and Health Conditions in the Oil Producing Communities in Central Senatorial District of Bayelsa State by Raimi et al., [2]; An Assessment of Trace Elements in Surface and Ground Water Quality in the Ebocha-Obrikom Oil and Gas Producing Area of Rivers State, Nigeria by Raimi Morufu Olalekan and Sabinus Chibuzor Ezugwu [3]; Health Risk Assessment on Heavy Metals Ingestion through Groundwater Drinking Pathway for Residents in an Oil and Gas Producing Area of Rivers State, Nigeria by Olalekan et al., [4]; The sources of water supply, sanitation facilities and hygiene practices in oil producing communities in central senatorial district of Bayelsa state, Nigeria 
by Olalekan et al., [5]; Bacteriological Assessment of Selected Hand Dug Wells in Students' Residential Area: A Case Study of Osun State College of Health Technology, Ilesa, Nigeria by Henry et al., [6]; The Sources of Water Supply, Sanitation Facilities and Hygiene Practices in an Island Community: Amassoma, Bayelsa State, Nigeria by Raimi et al., [7]; Digging deeper" evidence on water crisis and its solution in Nigeria for Bayelsa state: a study of current scenario by Olalekan et al., [8]; An Analysis of Bayelsa State Water Challenges on the Rise and Its Possible Solutions by Raimi et al., [9]; 21 ${ }^{\text {st }}$ Century Emerging Issues in Pollution Control. $6^{\text {th }}$ Global Summit and Expo on Pollution Control by Raimi [10]; Nigerians crying for availability of electricity and water: a key driver to life coping measures for deepening stay at home inclusion to slow covid-19 spread by Gift et al., [11]; Access to electricity and water in Nigeria: a panacea to slow the spread of Covid-19 by Gift and Olalekan [12]; Leaving No One Behind? Drinking-Water Challenge on the Rise in Niger Delta Region of Nigeria by Olalekan et al., [13]. Thus, the impact of water on all aspects of people's development is undeniable: a safe drinking water supply, sanitation for health, management of water resources, and improvement of water productivity can help change the lives of millions [4, 5, 7, 8, 9,13, 14]. Agwu [15], Morufu and Clinton [1] and Raimi and Sabinus [3] identifies Surface water (rivers, streams, lake and dams etc.) and Ground water (boreholes, wells etc.) as sources for drinking water. However, pollutants can be introduced into the natural water directly through point sources (septic tanks, disposal sites, industrial discharge of chemicals or spillage of oil, healthcare waste etc.,) near the source of water or indirectly through non-point source into the freshwater body by lateral or side movement [16, 17, 18, 19, 20]. More findings according to NOIPOLL in 2015 reveals significant proportion of Nigerians identified sachet water, popularly known as 'Pure water' as the major source of their drinking water in homes and offices. This source of drinking water might be affordable and easily accessible to Nigerians, but its hygiene and quality has been questioned by the National Agency for Food and Drug Administration and Control (NAFDAC) especially due to fault in the process of packaging. Other related sources of drinking water cited by NOIPOLL in 2015 include; taps water, private boreholes, and public boreholes.

Water is also a renewable resource in many parts of the world, water resources has become so depleted or contaminated that they are unable to meet ever-increasing demands [13, 21]. According to report in 2014 by United Nations, Nigeria was ranked the fifth dirtiest country in the world. 1.8 billion people globally use source of drinking water that is fecally contaminated. Some 2.4 billion people lack access to basic sanitation services, such as toilets or latrines $[5,7,8,9,11,12,13]$. Water scarcity affects more than 40 percent of the global population and is projected to rise [5, 7, 8,9]. More than 80 per cent of wastewater resulting from human activities is discharged into rivers or sea without any treatment, leading to pollution [22]. Water pollution is a global concern as risks of water quality degradation translate directly into environmental, health, social and economic problems $[23,24,25,26,27,28,29]$. Water pollution has also an impact on biological diversity of aquatic ecosystems, on which a wide range of sectors, from urban development to food production and industry, rely on. Improving water quality and wastewater management is a pre-requisite for access to clean water and sanitation [20, 30, 31, 32]. Homeowners are responsible for monitoring the quality of well water by testing for bacterial quality every 6 months; chemical quality every 2 years; and test more often if you notice changes in physical qualities - taste, smell, or colour. Regular testing alerts you to problems with your drinking water [33]. Access to a safe drinking water source located on premises, available when needed and free of faecal (and priority chemical) contamination, and bringing a safe water supply close to households is essential to prevent WASH- related diseases and facilitate hygiene by providing more water for a variety of purposes. It also addresses the gender inequity of the burden of water collection borne by women [2, $4,5,7,9,24,34]$. 


\subsection{Drinking Water Quality}

Drinking water must be free from pathogens and toxic chemicals. Drinking water quality management has two distinctive entry points: one related to the standards to be met on a day-to-day basis under routine operating conditions; the other related to managing incidents that threaten drinking water quality and may result in disease outbreaks $[1,2,3,8,11,12,13,34,35]$. Water quality criteria developed by scientists provides basic scientific information about the effect of water pollutants on a specific water use. Water quality criteria is based on variables that characterize the quality of water and/or the quality of the suspended particulate matter, the bottom sediment and the biota [20, 31]. A water quality index is collected by aggregating several water quality measurements into a single number. Indices are, therefore, simplified expressions of a complex set of variables. They have proved to be very efficient in communicating water quality information to decisions makers and to the public $[1,3,4,36]$. The parameters for determining water quality are highlighted as follows:

\subsubsection{Bacteriological Quality}

Coliform index is a measure of concentration of coliform organisms or E coli in a water sample. It is defined as the reciprocal of the smallest quantity of sample (in ml) which would give a positive E coli test. This index is now obsolete and now Most Probable Number (MPN). MPN is the bacterial density which if it had been actually present in the sample under examination, would more frequently than any other, have given the observed analytical results. For example, if 10 -ml standard portions are examined not more than $10 \%$ should show the presence of coliform bacteria, and if $100-\mathrm{ml}$ standard portions are examined not more than $60 \%$ should show the presence of coliform bacteria. When the membrane filter (MF) technique applied, the arithmetic mean coliform density of all standard samples must not exceed 1.0 per 100-ml. Moreover, coliform colonies per standard sample must not exceed 3/50-ml, 4/100-ml, 7/200-ml or 13/500-ml [6, 37]

\subsubsection{Physicochemical Quality}

Physicochemical indices are based on the values of various physicochemical qualities in a water sample. These are vital for water quality monitoring [2, 3, 4. 5, 7, 8, 38]. A number of scientific procedures and tools have been developed to assess the water contaminants $[8,9,13,39]$. These procedures include the analyses of different parameters such as $\mathrm{pH}$, turbidity, temperature, dissolved oxygen, alkalinity, fluoride, nitrate, sulphate, chlorides, iodine, lead, cadmium, manganese amongst others. These parameters can affect the drinking water quality, if their values are in higher concentrations than the safe limits set by the World Health Organization (WHO) and other regulatory bodies [1, 3, 13, 38].

\subsection{Health Effect/Impact of Drinking Unwholesome Water}

Contamination of drinking-water constitutes a major burden on human health $[1,3$, $4,7,8,9,13,40]$. Worldwide, millions of people, especially children, die from acute waterrelated diseases each year $[2,7,8,9,11,12,13]$. In addition to short-term diseases, drinking contaminated water can also cause a variety of chronic diseases such as cancer. Acute and chronic diseases caused by unsafe water influence the access to potable water (Grady et al., 2014; Raimi et al., 2017; Olalekan et al., 2019; Raimi et al., 2019; Olalekan et al., 2019; Olalekan et al., 2020) $[2,5,7,8,9,11,12,13,41]$. Chronic diarrhoea can hinder child development by impeding the uptake of essential nutrients that are critical to the development of children's minds, bodies, and immune systems [14, 42, 43, 44, 45, 46, 47, 48]. Accordingly, Raimi et al. [2], Morufu and Clinton [1], Raimi and Sabinus, [3] and Olalekan et al., [4] reiterates that poor water quality in Nigeria has caused several diseases such as cholera, dysentery, typhoid, poliomyelitis etc. They further buttress on how cholera alone has been the cause of thousands of deaths in Nigeria, and how the paucity of water has led to situations of untold suffering, affecting the impoverished and sustainable development. Heavy metals especially arsenic and lead in drinking water can bring about public health 
problems. Arsenic is one of the most dangerous trace elements and is predominantly found in rocks, soils, and natural water. It was reported that arsenic affects the organs and systems in the body, including skin, heart, respiratory organs, and kidney consequently leading to cancer of the lung, kidney, and bladder. Similarly, lead another heavy metal act as an anti-essential trace element and highly toxic cumulative element in the human body which is widely distributed in soil and groundwater [1,3,4]. For neurological, metabolic, and behavioural reasons, children are more vulnerable to the effects of lead compared to adults $[49,1,3,4]$. Intake of good quality water ultimately results in improved health. When you consume good quality water you are likely to have good health because about $70 \%$ of the body content is water.

\subsection{Water Supply and Sanitation Issues}

Many diseases endemic throughout the country in Nigeria are generally associated with unsatisfactory drinking water supplies, poor sanitation conditions and inadequate health education programs. However, the better access to potable water can help to relieve the total burden of disease (measured in daily-adjusted life years) and will help in the improvement of public health (Federal Republic of Nigeria, 2000; Olalekan et al., 2018; Raimi et al., 2019; Olalekan et al., 2019) [4, 5, 7, 8, 9, 50]. USAID in 2010 estimated that 54 percent of the Nigeria population lives on less than one dollar per day [11, 12, 13, 51, 52, 53]. Also, observed that total volume of water available in surface and ground water resources are sufficient to meet current drinking water demands, lack of distribution capacity, coupled with highly variable rainfall patterns has led to water scarcity in some areas, particularly the north. Accordingly, USAID 2010 also opined that water infrastructures have suffered from years of poor maintenance, and lack of adequate sanitation facilities constitutes very serious public health problem. Other factors are weak and inefficient institutions, unsustainable public sector spending, poor water quality and conflict over water use and management $[4,5,7,8,9,31]$.

On daily basis, over 800 children die from preventable diseases caused by poor water and lack of sanitation and hygiene [2, 5, 7, 8, 9, 11, 12, 51]. Globally, nearly 2.1 billion people lack access to safe drinking water in homes [2, 5, 7, 8, 9, 11, 12, 13]. By managing our water sustainably (water sanitation), we are able to better manage our production of food and energy and contribute to decent work and economic growth. Moreover, we can preserve our water ecosystems, their biodiversity, and take action on climate change $[4$, $11,12,20,24,31,33,52]$. Access to water and sanitation is considered core socio-economic and health indicators, and key determinants of child survival, maternal, and children's health, family wellbeing, and economic productivity. Drinking water and sanitation facilities are used in raising wealth quintiles used by many integrated household surveys to analyze inequalities between rich and poor [54]. Studies also observed that as water becomes scarcer at community water points, women and children who gather the water may find themselves at the forefront of inter and intra community-based conflict as they compete against each other for access to scarce water resources. The U.S National Action Plan on Women, Peace and Security, for instance, calls for building resilience through assistance that supports women's roles in the management of natural resources, mitigation of resource related conflict, and adaptation to climate change in fragile and conflict affected states $[24,33,52,55,56,57,58]$. Thus, answers were provided for the following research questions: To identifies all sources of drinking water in Piwoyi community; To examine the physicochemical and microbiological quality of drinking water in the selected sources of drinking water in Piwoyi Community; To determine the concentrations of some heavy metals in selected sources of drinking water in Piwoyi Community.

\section{Study Region}

\subsection{The Study Area [Abuja]}


Abuja is the Federal Capital Territory of Nigeria. The city is located at the center of the country. Abuja is a well-organized and planned city, built mainly in the 1980s. Abuja geography is classified by Aso Rock, a 400-metre (1,300 ft) monolith left by water erosion. The Presidential Complex, National Assembly, Supreme Court and much of the city extend to the south of the Zuma Rock, a 792-metre $(2,598 \mathrm{ft})$ monolith, lies just north of the city on the expressway to Kaduna. FCT lying between latitude $9^{0} 4^{\prime \prime}$ North of the equator and longitude $7^{0} 29^{\prime \prime}$ East of Greenwich Meridian (see figure 1 below), Abuja total landmass approximately is $7,315 \mathrm{~km}^{2}$. It is situated within the savannah region with moderate climatic conditions. Abuja Municipal Area Council covers 1,769km² (683 sq mi) Area, of which $1,728 \mathrm{~km}^{2}$ (667 sq mi) is land and $41 \mathrm{~km}^{2}$ (16 sq mi) is water [59].

\subsection{Demography of Abuja}

During 2006 census, Abuja population was among the ten most populous cities in Nigeria estimated around 776,298. Accordingly, the United Nations also confirmed that in 2015 that Abuja grew by 139.7\% between 2000 and 2010, making it the fastest growing city in the world. In 2015, the city is experiencing an annual growth of at least $35 \%$, retaining its position as the fastest growing city on the African continent and one of the fastest growing in the world. Also, in 2016, the metropolitan area of Abuja is estimated at six million persons.

\subsection{Climate}

Abuja climate classification features a tropical wet and dry climate. FCT has three weather conditions annually which are warm, humid rainy season and a blistering dry season. In between the two, there is a brief break of harmattan occasioned by the northeast trade wind, with the main feature of dust haze and dryness. Rainy season start from April and ends in October, when daytime temperature reach $28^{\circ} \mathrm{C}$ to $30^{\circ} \mathrm{C}$ and night-time lows hover around $22^{\circ} \mathrm{C}$ to $23^{\circ} \mathrm{C}$ in the dry season, daytime temperatures can soar as high as $40^{\circ} \mathrm{C}$ and night-time temperatures can dip to $12^{\circ} \mathrm{C}$.

\subsection{Vegetation}

FCT falls in the Guinean Forest-Savannah Mosaic zone of the West African sub-region. Patches of rain forest, however occur in Gwagwa plains, especially in the rugged terrain to the south eastern parts of the territory, where a landscape of gullies and rough terrain is found. These areas of the Federal Capital Territory (FCT) form one of the few surviving occurrences of the mature forest vegetation in Nigeria. 


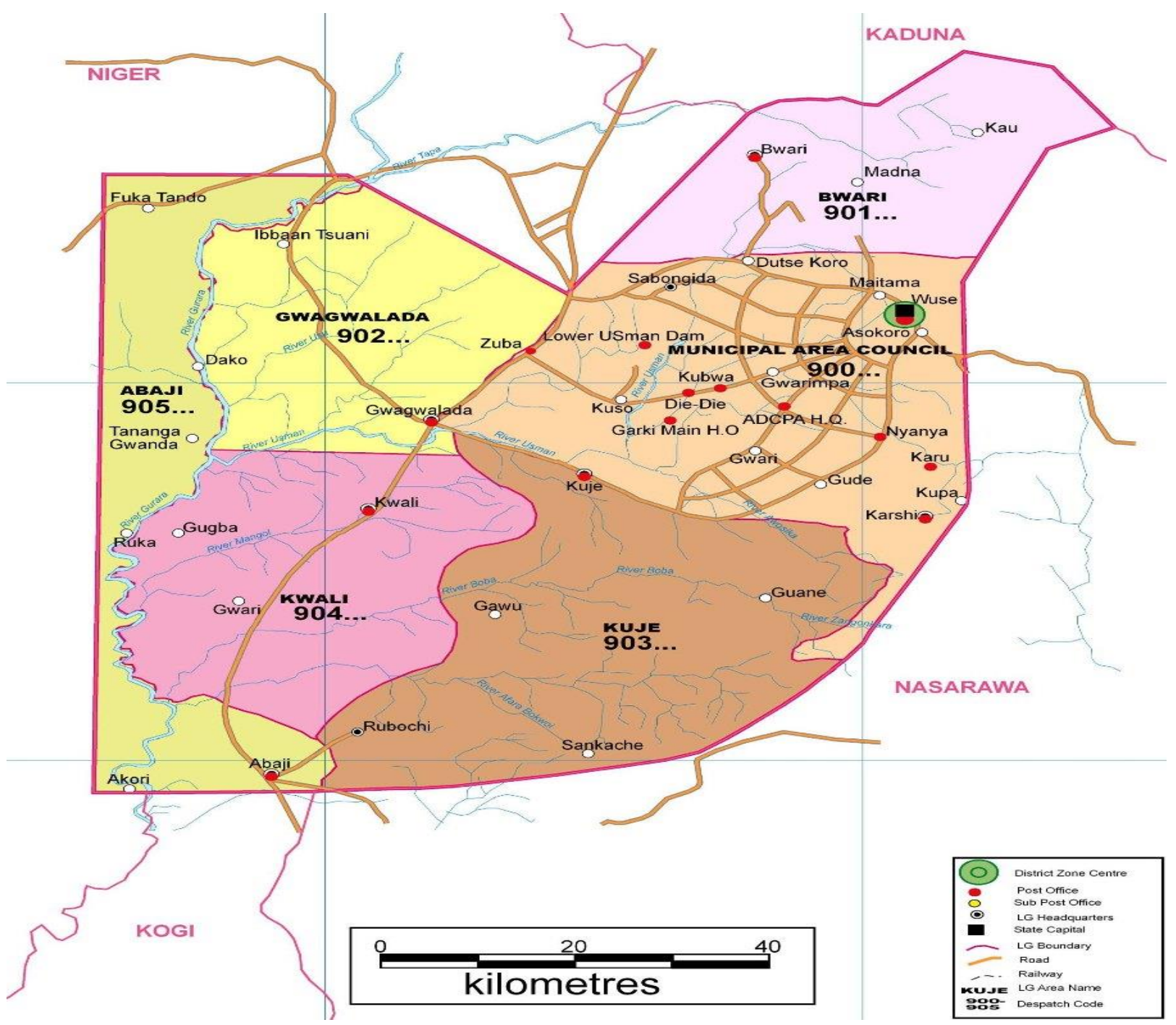

Figure 1. Map Showing the Study Area [Abuja FCT]

\subsection{About Piwoyi Community}

Piwoyi is one of clusters of satellite settlements in Abuja Municipal Area Council. It is located along KM 7.5, Umar Musa Yaradua Way, Airport Road, Abuja FCT, Nigeria. Piwoyi lies between latitude $8^{\circ} 99^{\prime} \mathrm{N}$ of the equator, and longitude $7^{\circ} 40^{\prime} \mathrm{E}$ of the Greenwich Meridian (see figure 1 above and figure 2 below). The community has some multipurpose structures which include Nigeria Defense College, Nike Art Gallery, Shoprite, National Assembly Annex, Schools, Hotels, Health Centre, other Government Offices, Companies as well as Living Premises. The postcode is 900107 (Postcode.info, 2013-2018). The composition of the people in Piwoyi community is heterogeneous comprises Gbagyi, Yoruba, Ibo and Hausa etc. Below is the Satellite Imagery of Piwoyi Community by NASRDA in 2012. 


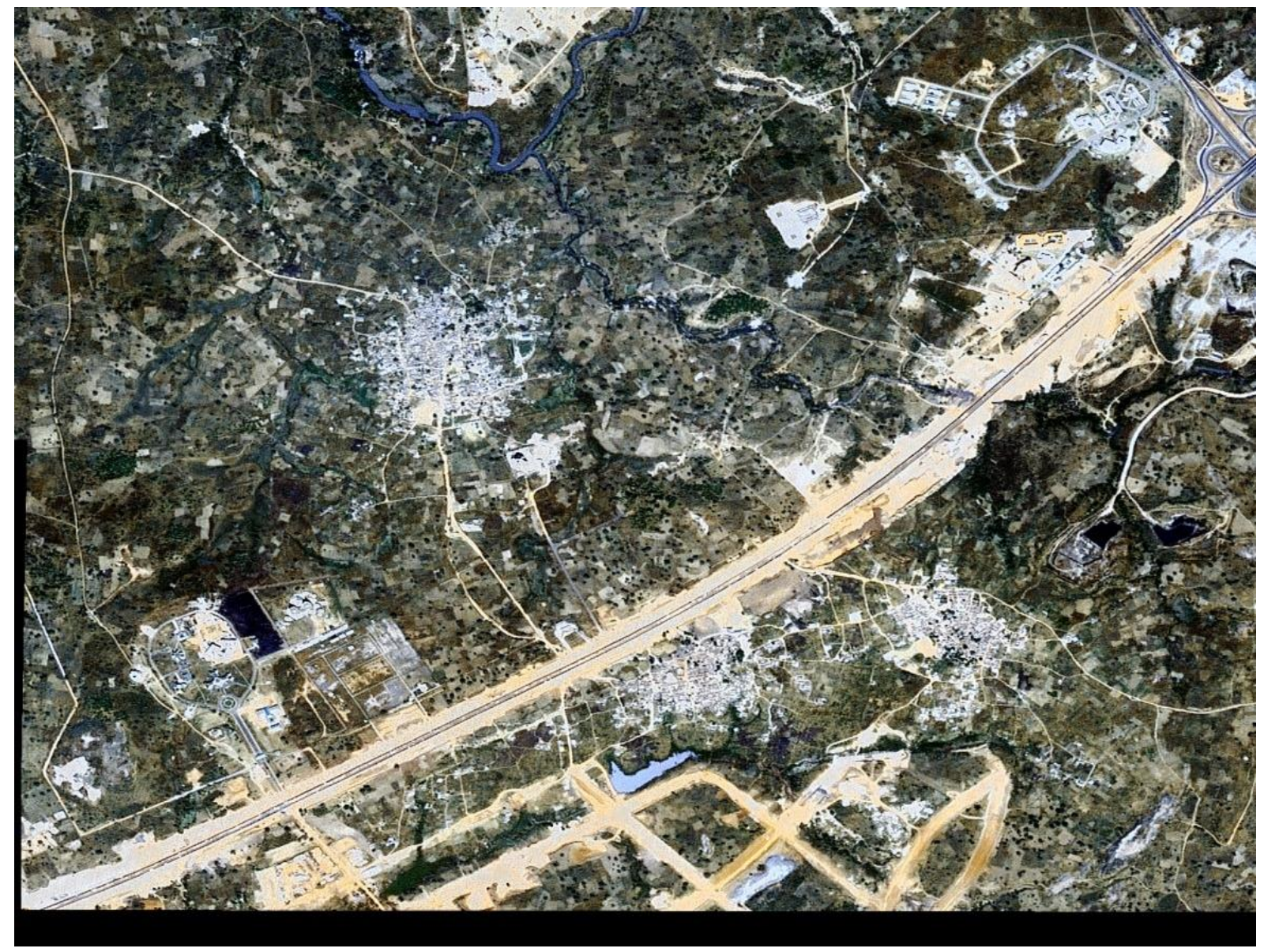

Figure 2. Map Showing the Satellite Imagery of Piwoyi Community

\section{Materials and Methods}

\subsection{Sampling and analytical techniques}

Water Samples were collected at different identified points viz-a-viz Mpape (P1), Baptist Church (P2), ECWA (P3), Chief Palace/Market (P4), Angwa Hausa (P5) and Sachet Water (P6). Most patronized borehole by water vendors and communal collecting water for drinking from different points were identified through direct observations and personal interview. Two different categories of Sachet water (Pure Water) used for drinking were also identified and most drink sachet water (Clime Sachet Water) was collected within Piwoyi Community.

\subsection{Sample Collection Time}

Raw Water Samples were collected at early hour of 6:00 am to 7:30 am under normal atmospheric temperature of $25^{\circ} \mathrm{C}$.

\subsection{Sample Bottle}

75cl distilled plastic bottles were used to collect raw water sample from different points.

\subsection{Sample Collection Procedure}

- Pre-printed label is attached to the bottle indicating the specific areas of collections for ease of identifications.

- The bottle sample is positioned to allow raw cold water to flow into it at a moderate rate from different sources identified.

- The bottle was filled just below the neck of the bottle. 
- The bottles were securely covered with tight lid to prevent leakage and kept in a cold box $\left(4^{\circ} \mathrm{C}\right)$ during transportation to the laboratory for analysis.

- Sachet water samples selected for this study were collected at the same time and transported to laboratory under normal conditions.

\subsection{Sampling, Preservation and Analysis}

The water sampling and the analysis follows standard procedures described in APHA [60]; Morufu and Clinton [1]; Raimi and Sabinus [3]; Olalekan et al., [4].

\section{Results and Discussion}

\subsection{Results}

The results of physicochemical and microbiological quality of drinking water including concentrations of some selected heavy metals are presented in table 1 below.

Table 1. Results of Physicochemical, Microbiological and Heavy metals parameters for drinking water (boreholes and sachet water) samples in comparison with NSDWQ (Nigerian Standard for Drinking Water Quality).

\begin{tabular}{|c|c|c|c|c|c|c|c|c|c|}
\hline Parameters & Units & $\begin{array}{l}\text { Mpape } \\
\text { (Point 1) }\end{array}$ & $\begin{array}{l}\text { Baptist } \\
\text { Church } \\
\text { (Point 2) }\end{array}$ & $\begin{array}{c}\text { ECWA } \\
\text { (Point 3) }\end{array}$ & $\begin{array}{l}\text { Chief Pal- } \\
\text { ace/Market } \\
\text { (Point 4) }\end{array}$ & $\begin{array}{c}\text { Angwa } \\
\text { Hausa } \\
\text { (Point } \\
5 \text { ) }\end{array}$ & $\begin{array}{l}\text { Clime } \\
\text { Sachet } \\
\text { Water } \\
\text { (Point 6) }\end{array}$ & NSDWQ & Remarks \\
\hline Conductivity & $\mathrm{uS} / \mathrm{cm}$ & 438 & 953 & 744 & 1027 & 487 & 90 & 1000 & BS-BS-BS-AS-BS-BS \\
\hline Temperature & ${ }^{\circ} \mathrm{C}$ & 29.3 & 29.3 & 29.3 & 29.3 & 29.2 & 27.2 & $27-28$ & AS-AS-AS-AS-AS-BS \\
\hline $\begin{array}{c}\text { Hydrogen Po- } \\
\text { tential }(\mathrm{pH})\end{array}$ & & 6.6 & 6.0 & 6.9 & 6.1 & 7.0 & 6.9 & $6.5-8.5$ & WS \\
\hline Turbidity & NTU & 3.0 & 4.0 & 9.0 & 18 & 15 & 20 & 5 & BS-BS-AS-AS-AS-AS \\
\hline $\begin{array}{c}\text { Total Dissolve } \\
\text { Solid (TDS) }\end{array}$ & $\mathrm{Mg} / \mathrm{L}$ & 294 & 639 & 499 & 688 & 326 & 60 & 500 & BS-AS-WS-AS-BS-BS \\
\hline $\begin{array}{c}\text { Dissolve Oxy- } \\
\text { gen (DO) }\end{array}$ & $\mathrm{Mg} / \mathrm{L}$ & 7.36 & 7.80 & 5.93 & 6.51 & 6.35 & 6.40 & 7.50 & WS-AS-BS-BS-BS-BS \\
\hline Chloride $\left(\mathrm{Cl}^{-}\right)$ & $\mathrm{Mg} / \mathrm{L}$ & 23 & 112 & 71 & 121 & 26 & 7.0 & 200 & BS \\
\hline $\begin{array}{c}\text { Total Hard- } \\
\text { ness (TH) }\end{array}$ & $\mathrm{Mg} / \mathrm{L}$ & 234 & 468 & 588 & 411 & 255 & 81 & 150 & AS-AS-AS-AS-AS-BS \\
\hline Alkalinity & $\mathrm{Mg} / \mathrm{L}$ & 266 & 187 & 210 & 143 & 239 & 56 & 100 & AS-AS-AS-AS-AS-BS \\
\hline Nitrate $\left(\mathrm{NO}_{3}{ }^{-}\right)$ & $\mathrm{Mg} / \mathrm{L}$ & 3 & 51 & 38 & 84 & 21 & 9 & 50 & BS-AS-BS-AS-BS-BS \\
\hline Calcium $\left(\mathrm{Ca}^{2+}\right)$ & $\mathrm{Mg} / \mathrm{L}$ & 72 & 85 & 87 & 80 & 68 & 29 & 75 & WS-AS-AS-AS-BS-BS \\
\hline $\begin{array}{c}\text { Magnesium } \\
\left(\mathrm{Mg}^{2+}\right)\end{array}$ & $\mathrm{Mg} / \mathrm{L}$ & 10 & 62 & 91 & 51 & 21 & 2 & 20 & BS-AS-AS-AS-AS-BS \\
\hline Phosphate & $\mathrm{Mg} / \mathrm{L}$ & 0.43 & 0.19 & 0.28 & 0.43 & 0.15 & 0.13 & 0.3 & AS-BS-WS-AS-BS-BS \\
\hline Phosphorous & $\mathrm{Mg} / \mathrm{L}$ & 0.15 & 0.03 & 0.06 & 0.15 & 0.02 & 0.01 & - & \\
\hline Sulphate & $\mathrm{Mg} / \mathrm{L}$ & 0 & 81 & 0 & 0 & 02 & 0 & 100 & BS \\
\hline Sodium & $\mathrm{Mg} / \mathrm{L}$ & 07 & 39 & 18 & 53 & 17 & 0 & 200 & BS \\
\hline Potassium & $\mathrm{Mg} / \mathrm{L}$ & 11 & 09 & 14 & 03 & 02 & 13 & 10 & AS-BS-AS-BS-BS-AS \\
\hline Fluoride & $\mathrm{Mg} / \mathrm{L}$ & 0.00 & 0.00 & 0.00 & 0.00 & 0.00 & 0.19 & 1.5 & BS \\
\hline Bicarbonate & $\mathrm{Mg} / \mathrm{L}$ & 266 & 187 & 210 & 143 & 239 & 56 & - & \\
\hline Nitrates $\left(\mathrm{NO}_{2}\right)$ & $\mathrm{Mg} / \mathrm{L}$ & 0.60 & 11.5 & 8.5 & 19 & 4.8 & 2.0 & 10 & BS-AS-BS-AS-BS-BS \\
\hline Nitrite $\left(\mathrm{NO}_{3}\right)$ & $\mathrm{Mg} / \mathrm{L}$ & 0.1 & 3.0 & 3.0 & 6.0 & 0.9 & 0.007 & 0.2 & BS-AS-AS-AS-AS-BS \\
\hline \multicolumn{10}{|c|}{ Microbiological parameters from selected boreholes and sachet water in comparison with NSDWQ } \\
\hline Coliforms & $\begin{array}{c}\mathrm{Cfu} / 100 \mathrm{~m} \\
1\end{array}$ & 02 & 70 & 180 & 04 & 06 & 30 & 10 & BS-AS-AS-BS-BS-AS \\
\hline
\end{tabular}




\begin{tabular}{|c|c|c|c|c|c|c|c|c|c|}
\hline E-coli & $\begin{array}{c}\mathrm{Cfu} / 100 \mathrm{~m} \\
1\end{array}$ & 00 & 27 & 65 & 01 & 01 & 11 & 0 & WS-AS-AS-AS-AS-AS \\
\hline Faecal Strep & $\begin{array}{c}\mathrm{Cfu} / 100 \mathrm{~m} \\
1 \\
\end{array}$ & 00 & 43 & 115 & 03 & 05 & 19 & 0 & WS-AS-AS-AS-AS-AS \\
\hline \multicolumn{10}{|c|}{ Heavy metals parameters from selected boreholes and sachet water in comparison with NSDWQ } \\
\hline Copper $\left(\mathrm{Cu}^{2+}\right)$ & $\mathrm{Mg} / \mathrm{L}$ & 0.05 & 0.20 & 0.16 & 1.0 & 0.07 & 0.00 & 1.0 & BS-BS-BS-WS-BS-BS \\
\hline Iron $\left(\mathrm{Fe}^{2+}\right)$ & $\mathrm{Mg} / \mathrm{L}$ & 0.32 & 0.00 & 3.30 & 0.00 & 0.00 & 0.00 & 0.3 & AS-BS-AS-BS-BS-BS \\
\hline Zinc $\left(\mathrm{Zn}^{2+}\right)$ & $\mathrm{Mg} / \mathrm{L}$ & 1.13 & 3.27 & 2.10 & 3.37 & 1.10 & 0.00 & 5 & BS \\
\hline
\end{tabular}

Source: Field Survey

Note: BS - Below Standard, AS - Above Standard, WS - Within Standard

Table 1 shows the results of the assessment of the quality of drinking water in Piwoyi community of Federal Capital Territory, Abuja. Results shows borehole and sachet water in the six (6) locations measured for physico-chemical parameters analysed. For conductivity, Mpape, Baptist church, ECWA, Angwa Hausa and Clime sachet water were all below Nigerian standard for drinking water quality (NSDWQ). While Chief palace/market were above recommended standard. Temperature from point 1 to point 5 were above recommended standard, while, clime sachet water were below standards. $\mathrm{pH}$ was within recommended standards in all locations. Turbidity at ECWA, Chief palace/Market, Angwa Hausa and Clime sachet water were above recommended standards. For TDS, Batist church, Chief palace/Market were above standards. DO, only point 2 is above recommended standards. For Chloride, all samples taken taken are below standards. Total hardness (TH) from point 1 to 5 are above recommended standards. Same goes for Alkalinity. For Calcium, point 2, 3 \& 4 were above recommended standards. Magnesium at point 2, 3, $4 \& 5$ are above recommended standards, Phosphate at point $1 \& 4$ are above standards. Sulphate in all locations are below standards. Same goes for Sodium and Fluoride. Potassium at point $1,3 \& 6$ are above standards. Nitrate at point $2 \& 4$ are above standards, Nitrite at point 2, 3, $4 \& 5$ are above recommended standards. For microbiological parameters, Coliform at point $2,3 \& 6$ are above recommended standard, E-coli at point 2, 3, 4, 5 \& 6 are above recommended standards. Same goes for faecal strep. For Heavy Metal, Copper and Zinc in all locations fall below NSDWQ recommended standards. Iron at point $1 \& 3$ are above recommended standards.

\subsection{Discussion}

\subsubsection{Comparison of Physicochemical and Heavy metals results of drinking water samples analysis with Nigerian Standard for Drinking Water Quality (NSDWQ).}

Water chemistry depends on various factors such as geological and hydrogeological settings, intensity and rate of rock weathering, climatic conditions, recharge water quality, types and intensity of human activities, and connections and interactions of different water bodies $[2,3,4,57,8,9,13,31]$. These factors vary in different environments, and their interactions can create complex water chemistry $[1,3,4,5,10]$. To explore the general hydrochemistry of water in the study area, the statistical summary of borehole water and sachet water is presented in Table 1. Thus, water in Piwoyi community of Federal Capital Territory, Abuja is mainly used for domestic and agricultural purposes. Physiochemical indices were compared with the Nigerian Standard for Drinking Water Quality and World Health Organization guidelines for drinking water quality purpose.

Indeed, pure water is not a good conductor of electric current rather a good insulator. Increase in ions concentration enhances the electrical conductivity of water. Generally, the amount of dissolved solids in water determines the electric conductivity. According to Nigeria standard, electrical conductivity should not exceed $1000 \mathrm{uS} / \mathrm{cm}$. But the value obtained from Mpape (438), Baptist Church (953), ECWA (744), Angwa Hausa (487) and Clime Sachet Water (90) are below the permissible level except Chief Palace/Market that 
is higher (1027). Hence, the spatial distribution shows a higher EC towards the Chief Palace/Market. Indicating that man-made activities and geochemical processes greatly responsible for the increase in EC. The temperature is one of the most important factors that affect the biological activity of aquatic organisms. The average temperature value of the water samples (Boreholes and sachet water) in the study area ranges between $27.2^{\circ} \mathrm{C}$ and $29.3^{\circ} \mathrm{C}$. Temperature in this study was found to be within the permissible level of WHO $30^{\circ} \mathrm{C}$ and NSDWQ. Turbidity is caused by organic detritus; silica and other mineral substances such as zinc, iron, clay and microorganisms. Turbidity is the characteristics of water which causes light to scatter and absorbed rather than transmitting in straight lines. Maximum turbidity permitted as per Nigerian standard is $5 \mathrm{mg} / \mathrm{l}$. The turbidity value of water sample is higher in ECWA (9.0), Chief Palace/Market (18), Angwa Hausa (15) and Clime Sachet Water (20) but lower in Mpape (3.0) and Baptist Church (4.0) area respectively. Thus, excess Turbidity according to Morufu and Clinton [1]; Raimi and Sabinus [3]; Olalekan et al., [4]; Olalekan et al., [13] makes the water not appealing for recreation, spiritualism and gives poor visibility due to reduction in the amount of sunlight scattered or absorbed by particulates. Furthermore, the high turbidity is indicative of high volume of suspended particulate matters (silt, clay, waste effluents etc.). High volume of turbidity according to Morufu and Clinton [1], Raimi and Sabinus [3], Olalekan et al., [4]; Olalekan et al., [13] held that excessive dissolved solids can give a kind of taste to water, increases corrosion or encrustation of metallic equipment and poses problems to household plumbing and other utensils (boilers, toilet flushes, washing machines, metallic plates and faucets). The hydrogen ion concentration of $\mathrm{pH}$ is a parameter that shows the chemical and biological characteristics and it is used in classifying alkalinity or acidity of waters. While, the $\mathrm{pH}$ of water is a measure to determine acidic and alkaline character in water. Principal system that regulates $\mathrm{pH}$ in natural water is carbonate system which comprises $\mathrm{CO}_{2}$, $\mathrm{H}_{2} \mathrm{CO}_{3}$ (Carbonic acid) and $\mathrm{HCO}^{3-}, \mathrm{CO}^{3-}$ value of $\mathrm{pH}$ of good quality water varies between 6.5 and 8.5. In addition, drinking water normal $\mathrm{pH}$ level varies between 6.5 and 8.5. Thus, current investigations depict average normal $\mathrm{pH}$ value in Mpape (6.6), ECWA (6.9), Angwa Hausa (7.0) and Clime Sachet water (6.9) except Baptist Church (6.0) and Chief Palace (6.1) fall within the acidic level, indicating that point 2 and 4 is generally slightly acidic. These $\mathrm{pH}$ values are slightly lower than those of other locations. These results indicate that the study area has basic character and is in Class-I (6.5-8.5) in terms of $\mathrm{pH}$ value. On pH scale, a value 7 is refers to as neutral water, below 7 is acidic water while any value above 7 is basic water $[1,3,4,10,13]$. Water has the ability to dissolve both organic and inorganic minerals and salts, such as potassium, calcium, sodium, bicarbonates, chlorides, magnesium and sulphates. These minerals produced unwanted taste and diluted colour in appearance of water. Water with high level of Total Dissolve Solid (TDS) indicates that the water is highly mineralized. Desirable limits according to Nigeria standard is 500mg/l. However, the study shows high TDS in Baptist Church (639), Chief Palace/Market (688), and others are within the acceptable limits in Mpape (294), ECWA (499), Angwa Hausa (326) and Clime Sachet Water (60). High value of TDS in ground water are generally not harmful to man, but high concentrations of these may affect persons who are suffering from kidney and heart diseases [13]. Water containing high solid may cause laxative or constipation effect $[1,3,4]$. It major causes include saline water intrusion, ejection of untreated domestic wastewater, beach placer mining of coastal sand dunes, and lithological formation of salt in subsurface rocks [31]. These groundwater with elevated TDS can cause gastrointestinal irritation, heart disease and kidney stones in humans $[1,3,4,13,61]$. Adequate dissolve oxygen is necessary for good water quality. Oxygen is necessary element to all forms of life. Oxygen affects vast number of other water indicators, not only biochemical but aesthetic ones like the odour, clarity and taste. The desirable limits for Dissolve Oxygen is $6 \mathrm{mg} / \mathrm{l}$. Therefore, the results of analysis show an increase in dissolve oxygen above $6 \mathrm{mg} / \mathrm{l}$ except ECWA at 5.93. Furthermore, chlorides is obtained from natural deposits of sedimentary rocks or dissolution of salts of hydrochloric acid as table salt 
$(\mathrm{NaCl}), \mathrm{NaCO}_{2}$, and added through sewage etc. High concentration of chlorides may be injurious to people suffering from heart and kidney diseases. $200 \mathrm{mg} / \mathrm{l}$ is maximum as Nigeria standard. All the sample areas are within the permissible level by Nigeria standard. Hard water is water that has high mineral content and it is formed when water percolates through deposits of limestone and chalk which are largely made up of calcium and magnesium carbonates. Total hardness is expressed as the sum total of magnesium and calcium concentrations of $2-4 \mathrm{mmol} / \mathrm{L}$. The desirable standard for Total Hardness in water is $150 \mathrm{mg} / \mathrm{l}$. The results of analysis shows that all the samples of water collected from boreholes are hard. The Clime sachet water is within the desirable limit of $80 \mathrm{mg} / \mathrm{l}$. Thus, longterm dietary exposure to hard to very hard water may lead to increased incidences of health problems such as anencephaly, parental mortality, and cardiovascular disorders [4, 13].

Alkalinity is a measure of the capacity of water to neutralize acids or hydrogen ions. Alkalinity acts as buffer if any changes are made to the water's $\mathrm{pH}$ value. Alkalinity will help to keep the water's $\mathrm{pH}$ stabilized. The drinking water should have a neutral $\mathrm{pH}$ of 7 . High alkalinity is good to have in our drinking water because it keeps the water safe for us to drink. The amount of alkalinity that should be in our water is $20-200 \mathrm{mg} / \mathrm{l}$ for typical drinking water. Alkalinity is basically dissolved minerals in the water that help neutralize the water we drink. While, alkali strength is a measurement of the water tenure of free carbonate and caustic alkali. $\mathrm{HCO}_{3}$ - water varies during the study from 56 to $266 \mathrm{mg} / \mathrm{l}$ (Table 1). The maximum value is $100 \mathrm{mg} / \mathrm{l}$. According to Nigerian standard for drinking water quality, $\mathrm{HCO}_{3}$ - is an indicator of the presence of ions carbonates, bicarbonates, hydroxides hardness of drinking water factor. The results of analysis shows that alkalinity in Baptist Church (187), Chief Palace/Market (143), and Clime Sachet Water (56) are within the desirable limit while it is higher in Mpape (266), ECWA (210), and Angwa Hausa (239). Nitrate occurs naturally at very low concentrations in groundwater and is regarded as an important plant nutrient. Common sources of nitrate in groundwater are from inorganic fertilizers and manures, wastewater disposal on land for irrigation and oxidation of nitrogenous waste products in human or animal excreta $[1,3,62,63]$. Main source of nitrates in water is from atmosphere, sewage, industrial effluents and agriculture. When water contains excess amount of nitrates and is ingested, bacteria convert these nitrates to nitrites. These nitrites react with secondary amine present in the food and form nitro compounds responsible for methamoglobonimeaic diseases in children. Nigeria desirable standard for nitrate is $50 \mathrm{mg} / \mathrm{l}$. The study shows that nitrates is higher in Baptist Church (51), Chief Palace/Market (84), which is due to anthropogenic sources like application of agricultural fertilizers $[13,42,43,45,46,47,48,63]$. This led to nitrate concentrations exceeding the WHO limit in $5 \%$ of the locations. Nitrate contamination is usually associated with shallow groundwater [1, 3, 4, 62, 13]. Raimi et al. [63] [9] [13] reported that pit latrines and public water points are observed to influence nitrate concentrations in borehole water of Baptist Church and Chief Palace/Market. This may also be another reason for an increase in nitrate concentration in borehole water in the study area. Mpape (03), ECWA (38), Angwa Hausa (21) and Clime Sachet Water (09) are within the permissible level. Thus, nitrate concentration in Mpape, ECWA, Angwa Hausa and Clime Sachet Water is lower than the guideline value, indicating suitability of the water for drinking purpose.

While, calcium $\left(\mathrm{Ca}^{2}+\right)$ is very essential element for human body. It serves as nutrient and body requires $0.7-2.0 \mathrm{mg}$ of calcium daily. When the human body lacks $\mathrm{Ca}^{2+}$, it leads to several diseases such as stroke, osteoporosis, and colorectal cancer. Its deficiency causes rickets and presence prevents absorption and transfer of toxic ions from intestine to blood. Excess amount can cause damage to kidney and impart hardness to water. The maximum desirable standard is $75 \mathrm{mg} / \mathrm{l}$. However, the results of analysis shows that calcium in sample water collected were higher in Baptist Church (85), ECWA (87), Chief Palace/Market (80), and within the desirable level in Mpape (72), Angwa Hausa (68) and Clime Sachet Water (29). Thus, drinking such water samples could yield ailments in the human body 
such as hypertension, kidney stones, osteoporosis, stroke, and colorectal cancer [40, 4, 64, 13]. In addition, the high calcium concentration in Baptist Church, ECWA and Chief Palace/Market implies that the water is polluted and unfit for consumption due to calcium contribution to overall hardness in concert with magnesium and sulphates. This represents a risk of changes in bowel habits (diarrhoea) and Cholera [2, 5, 7, 13]. Presence of magnesium in excess amount acts as a laxative agent and causes hardness of water which may further cause cardiovascular mortality. Its deficiency makes a person susceptible to cardiac and may also cause sudden unexpected infant death syndrome. The maximum desirable Nigeria standard is $20 \mathrm{mg} / \mathrm{l}$. However, the result of analysis depicts high level of magnesium in Baptist Church (62), ECWA (91), Chief Palace/Market (51), Angwa Hausa (21), and within the desirable level in Mpape (10) and Clime Sachet Water (02). Thus, combinations of calcium and magnesium ions reduces the soil permeability and affect soil structure, drainage pattern as well as crop production. The phosphate exists in three forms: orthophosphate, meta-phosphate, and organically bound phosphate, each compound contains phosphorus in different chemical arrangements $[3,4,8,9,13]$. Phosphates are chemical compounds containing phosphorous. Manmade sources for phosphate include human sewage, agricultural run-off from crops, sewage from animal feedlots, pulp and paper industry, vegetable and fruit processing, chemical and fertilizer manufacturing and detergents [13, 20, 42, 43, 45, 46, 47, 48, 63]. Phosphates itself does not have notable adverse health effect. However, phosphate levels greater than $1.0 \mathrm{mg} / \mathrm{l}$ may interfere with coagulation in water treatment processes. The results of analysis are within the desirable limits. Thus, phosphate support heavy aquatic plant growth that usually leads to algal blooms $[1,3,4,5,8,9,13,20]$. This is a non-metallic element which is necessary for life and is found in rock as inorganic phosphates. Phosphorous plays a role in deoxyribonucleic acid (DNA), adenosine diphosphate (ADP), and adenosine triphosphate (ATP). Phosphorous is required for these necessary components of life to occur. Presence of sulphate in drinking water affects taste and in excess amount causes diseases called catharsis or purgation of alimentary canal. The maximum desirable Nigeria standard for sulphate is $100 \mathrm{mg} / \mathrm{l}$. However, Sulphates results of analysis in the water sources were identified in all the samples analysed to be within the desirable level of NSDWQ standard limits. While excess sulphate concentration might likely cause dehydration, catharsis in adults $[1,3,4,65]$. Sodium is a silver white metallic element and found in less quantity in water. Adequate quantity of sodium in human body prevents many fatal diseases like kidney damage, hypertension, headache etc. The maximum Nigeria standard for sodium in drinking water is $200 \mathrm{mg} / \mathrm{l}$. However, the results of analysis depict that sodium are below the desirable limits of the drinking water sample. Even though sodium is essential for balanced human health, excessive sodium intake can lead to serious health risks such as vomiting, hypertension and osteoporosis and high blood pressure [1, 3, 4, 13, 40, 66]. While, excess concentrations of sodium in water are indicative of reduced ionic and microbial activities as well as increased water density. According to WHO [65], sodium salts are not acutely toxic because of the efficiency with which mature kidneys excrete sodium. However, acute effects and death have been reported following accidental overdoses of sodium chloride. Potassium is a silver white alkali which is highly reactive with water. Potassium enhances human body functions like heart protections, regulation of blood pressure, protein dissolution, muscle contraction and nerve stimulus. Its deficiency may cause depression, muscle weakness, heart rhythm disorder etc. The max desirable Nigeria standard for potassium is $12 \mathrm{mg} / \mathrm{l}$. However, the results of analysis shows that potassium is higher in ECWA (14) and Clime Sachet Water (13), which is found to be above Nigerian standard for drinking water quality (NSDWQ), and Mpape (11), Baptist Church (9), Chief Palace/Market (03), and Angwa Hausa (04) are within the permissible limit. Thus, high as well as abnormal concentrations could be due to artificial compost in farming measures such as leaching or percolating into the subsurface and weathering of $\mathrm{K}^{+}$bearing minerals in rocks nearby 
[31]. This enriched $\mathrm{K}^{+}$could cause nerve and digestive disorders [13, 61]. Equally, Potassium is needed for the proper functioning of cells, notwithstanding, excess intake of it could possibly lead to high blood pressure (HBP), medically called hyperkalaemia, together with chest tightness, nausea, vomiting, diarrhoea, shortness of breath, heart failure, haemolyticanaemia and Addison disease $[1,3,4,67]$. Fluoride occurs in nature in the form of $\mathrm{CaF}_{2}$, cryolite, $\mathrm{Na}_{3} \mathrm{AlF}_{6}$ and flurapatile. Fluoride contents are also found in food like fish, tea, milk, fruits and vegetables. Its increased contents beyond certain limits cause fluorosis destruction of enamel of teeth. The Nigeria standard for fluoride is $1.5 \mathrm{mg} / \mathrm{l}$. However, the analysis of results in all samples depicts that fluoride is within the desirable limit. However, it is also essential to pay attention to the fluorine content in borehole and sachet water since the residents in the study area could likely be suffering from fluorosis in the nearest future. $\mathrm{F}-$ is beneficial at low concentrations but toxic at high concentrations in drinking water $[1,3,4,13]$.

Nitrogen is derivatives of nitrite $\left(\mathrm{NO}_{2}\right)$, nitrate $\left(\mathrm{NO}_{3}\right)$ and ammonium nitrogen $\left(\mathrm{NH}_{4}{ }^{+}\right)$ Recently, one of key sources of nitrite $\left(\mathrm{NO}_{2}\right)$ in waters are fertilizers, organic matters, and some of minerals $[13,20]$. The desirable standard for Nitrite $\left(\mathrm{NO}_{2}\right)$ is $0.2 \mathrm{mg} / \mathrm{l}$. The health impact of nitrite is cyanosis and asphyxia (blue-baby syndrome) in infants under 3 months. The result of laboratory analysis for nitrites was high in Baptist Church (3.0), ECWA (3.0), Chief Palace/Market (6.0), thus indicating pollution and Mpape (0.1), Angwa Hausa (0.9) and Clime Sachet Water (0.007) are within desirable limit. Nitrate pollution of water is a widespread issue and the desirable standard for $\mathrm{NO}_{3}-\mathrm{N}$ in drinking water is $10 \mathrm{mg} / \mathrm{l}$. The health impact of $\mathrm{NO}_{3}-\mathrm{N}$ is Methemoglobinemia in infants. The most obvious symptom of methemoglobinemia is a bluish color of the skin, particularly around the eyes and mouth. Other symptoms include headache, dizziness, weakness or difficulty in breathing. However, the study reveals very high nitrate-nitrogen in Baptist Church (11.5) and Chief Palace/Market (19), which indicates high concentrations and other four points areas analyzed are within the permissible level. Even though nitrates have no direct toxic effects except at high doses, the fact that they can give birth to nitrites leads to toxicity. Copper toxicity is much overlooked contributor to many health problems such as anorexia, fatigue, premenstrual syndrome, depression, anxiety, liver and kidney damage, migraine and headaches, allergies, childhood hyperactivity and learning disorders. The desirable limit for copper in water is $1 \mathrm{mg} / \mathrm{l}$. The results of analysis shows that copper is within the desirable limit in all samples collected in Piwoyi community. Iron is the second most abundant metal on the earth's crust $[1,3,4,68]$. Iron occupies the $26^{\text {th }}$ elemental position in the periodic table. Iron is a most crucial element for growth and survival of almost all living organisms [4, 69]. It is one of the vital components of organisms like algae and of enzymes such as cytochromes and catalase, as well as of oxygen transporting proteins, such as hemoglobin and myoglobin $[1,3,4,70]$. Iron is an attractive transition metal for various biological redox processes due to its inter-conversion between ferrous $\left(\mathrm{Fe}^{2+}\right)$ and ferric $\left(\mathrm{Fe}^{3+}\right)$ ions [71]. The source of iron in groundwater is anthropogenic and is related to mining activities. The production of sulphuric acid and the discharge of ferrous $\left(\mathrm{Fe}^{2+}\right)$ takes place due oxidation of iron pyrites $\left(\mathrm{FeS}_{2}\right)$ that are common in coal seams [69]. While, iron is found in the form of $\mathrm{FeCl}, \mathrm{Fe}\left(\mathrm{HCO}_{3}\right), \mathrm{FeSO}_{4}$. Iron helps in metabolic process of human health. Presence in excess amount imparts objectionably colour and taste. The maximum desirable Nigeria standard for iron in water is $0.3 \mathrm{mg} / \mathrm{l}$. The result of analysis shows high concentration of iron in Mpape (0.32) and ECWA (3.30) and within the acceptable limit in other sample areas with 0.00 . In the Niger Delta Region of Nigeria, many people have been exposed to elevated levels of iron through drinking water, as the collected groundwater exceeded the tolerable limit set by the NAFDAC and WHO on the quality of drinking water $[1,3,4,10,13,31]$. Similarly, the abundance of species such as periphyton, benthic invertebrates and a fish diversity are greatly affected by the direct and indirect effects of iron contamination $[1,3,4,20,70]$. The iron precipitate will cause considerable damage by means of clogging action and hinder the respiration of fishes [31, 68]. Thus, iron being 
the most abundant transition metal in the earth's crust. Biologically it is the most important nutrient for most living creatures as it is the cofactor for many vital proteins and enzymes. Iron mediated reactions support most of the aerobic organisms in their respiration process. If it is not shielded properly, it can catalyze the reactions involving the formation of radicals which can damage biomolecules, cells, tissues and the whole organism. Iron poisoning has always been a topic of interest mainly to pediatricians. Children are highly susceptible to iron toxicity as they are exposed to a maximum of iron containing products [72]. Zinc is an important mineral apparent by the human today as being excellent biologic and human health significance, mainly concerning prenatal and perinatal growth. Zinc deficiency effects around two billion public in the rising global and is related with several illnesses. In children its causes development delay, late sexual development, infection vulnerability, and diarrhea. Enzymes with a zinc particle in the sensitive focus are extensive in chemistry, such as liquor dehydrogenase in people Zinc insufficiency is generally due to unsatisfactory dietary consumption, but can be correlated with malabsorption, Acrodermatitis enteropathica, liver damage, renal damage, sickle cell damage, diabetes, malignancy, and other chronic diseases assemblies at hazard for zinc deficiency contain the elderly, children in rising nations, and individuals with renal deficiency. Signs of mild zinc insufficiency are varied. Medical consequences contain depressed development, diarrhea, weakness and late sexual development, alopecia, eye and skin abrasions, decreased appetite, changed perception, decreased host protection possessions, defects in carbohydrate utilization, and reproductive spermatogenesis $[5,7,8,9,13]$. Thus, excess amount of zinc imparts a stringiest taste and milky appearance to water. Maximum limit according to Nigeria standard is $5 \mathrm{mg} / \mathrm{l}$. The results of analysis show that zinc is within the desirable limit.

Accordingly, the high levels of turbidity, total dissolved solids, total hardness, alkalinity, nitrate, nitrite, phosphate, calcium, magnesium, potassium and iron in most of the water sources are indicative of high level of bioaccumulation with its resultant adverse human health effect on Piwoyi community. Consequently, urgent site-specific review of the Nigerian standard for drinking water quality (NSDWQ) as earlier posited by Raimi $e t$ al., [23], Omidiji and Raimi, [25]. Olalekan et al., [26]; Adedoyin et al., [27], Olalekan et al., [28] and Raimi et al., [29] is imperative. Morufu and Clinton [1], Raimi and Sabinus [3], Olalekan et al., [4], Raimi, [10] and Olalekan et al., [13] report that trace metals negatively impact water quality. They are carcinogenic, mutagenic as well as genotoxic to humans and organisms. They are persistent organic compounds, soluble or insoluble in forms, dictated by their valence, with acute or chronic adverse health effects. Morufu and Clinton [1], Raimi and Sabinus [3], Olalekan et al. [4], Raimi, [10] and Olalekan et al. [13] reports that elevated PAHs and THC in water, from epidemiological and experimental studies poses great human health challenges and cause deaths when ingested even at trace concentrations in all environmental matrices. This is due to their bioaccumulation, biomagnifications and bioamplication capabilities over time in the tissues of man and organisms. EFSA [73] report that hyper-reactivity of xeynobiotics is exacerbated by temperature, phase association, adsorption, sequestration, speciation at thermodynamic equilibrium, complexion kinetics, lipid solubility, octanol/water partition coefficients, species characteristics, trophic interactions, adaptations in flora and fauna; being vital components of many enzymes in many redox reactions. The study reveals physio-chemical parameters and some heavy metals are in excess of NSDWQ permissible limits in all locations except chloride, sulphate, sodium, fluoride, copper and zinc. Olalekan et al., [13] reports that heavy metals are biopersistent in recipient's system for a long time and cause renal dysfunction, lung cancer, bone disorders (Osteomalacia and Osteoporosis) and increases blood pressure and myocardium in a variety of animals. Morufu and Clinton [1], Raimi and Sabinus [3], Olalekan et al. [4], Raimi, [10] and Olalekan et al. [13] reports that zinc, magnesium and potassium, rank amongst one of the top 10 heavy metals with lethal pub- 
lic health significance. They induce multiple organ damage even at low concentration exposure. Thus, the study populations are most likely to suffer from one or a mixture of foetus and infant mutilations or deaths, haemoglobin synthesis, kidney and gastrointestinal tract issues, joints weakness, reproduction systems complications, nervous system problems and other subclinical neuropsychological growths in infants and blood level rise. Findings in this study are therefore in agreement with Morufu and Clinton [1], Raimi and Sabinus [3], Olalekan et al. [4], Raimi, [10] and Olalekan et al. [13] in oil polluted milieu in which zinc, copper, manganese were below permissible limits, hence were unlikely to cause any adverse effects during a person's life time, except for prolonged bioaccumulation and amplification, which could disturb human health.

\subsubsection{Microbiological Comparison to Nigerian Standard for Drinking Water Quality (NSDWQ) Acceptable Risk Benchmark}

The term "total coliforms" refers to a large group of Gram-negative, rod-shaped bacteria that share several characteristics. The group includes thermotolerant coliforms and bacteria of faecal origin, as well as some bacteria that may be isolated from environmental sources. Thus, the presence of total coliforms may or may not indicate faecal contamination. In extreme cases, a high count for the total coliform group may be associated with a low, or even zero, count for thermotolerant coliforms. Such a result would not necessarily indicate the presence of faecal contamination. It might be caused by entry of soil or organic matter into the water or by conditions suitable for the growth of other types of coliform. Hence, the bacteriological analysis of water determines the potability of water. According to Nigeria standard for drinking water quality (NSDWQ) throughout the year $95 \%$ of samples should not contain any coliform organisms or should not be detectable in $100 \mathrm{ml}$ of any two consecutive samples and no sample contains E. coli in 100ml. The desirable limit of coliform according to Nigeria standard in water is $10 \mathrm{cfu} / \mathrm{ML}$. The result of analysis depicts that water samples in Baptist Church (70), ECWA (180), and Clime Sachet Water (30) depicts high coliform count. Thus, indicating faecal contamination of water with high amount of bacterial population than Nigeria acceptable limit. The reason for high number of bacterial colonies might be due to inadequate maintenance of water reservoirs and the mixing of sewage into the reservoirs or directly into the rivers. In Baptist Church (70), ECWA (180), and Clime Sachet Water (30), the high total coliform count may be indicative of the presence of high organic compounds in the water, resulting from animal and human wastes. These sources of bacterial contamination include surface runoff, pasture, and other land areas where animal wastes are deposited. Additional sources include seepage or discharge from septic tanks, sewage treatment facilities and natural soil /plant bacteria $[2,6,13,74]$. This is similar to Rajurkar et al. [75] and Radha Krishnan et al. [76] who found that the high number of total coliforms were observed by different authors in different water bodies in India during pre-monsoon and post monsoon seasons. Others are within the permissible 2-6. While, Nigeria desirable standard for E-coli is 0cfu/mL. Presence of Ecoli can result in urinary tract infections, bacteraemia, meningitis, diarrhoea (one of the main causes of morbidity and mortality among children), acute renal failure and haemolytic anaemia. The result of analysis for E-coli was high in Baptist Church (27), ECWA (65), Chief Palace/Market (1), Angwa Hausa (1) and Clime Sachet Water (11). No presence of E-coli in Mpape. Hence, these areas contain excessive E. coli per liter, which is much higher than the guideline value for drinking purpose ( $3 \mathrm{E}$. coli per liter). This indicates a serious contamination from excrement of livestock and local residents in this area, and poses the biggest threat to the suitability of water for drinking purpose. The presence of faecal streptococci is evidence of faecal contamination. Faecal streptococci tend to persist longer in the environment than thermotolerant or total coliforms and are highly resistant to drying. This is an indication of recent faecal contamination. The acceptable level for Faecal Strep is $0 \mathrm{cfu} / \mathrm{mL}$. There are clear evidence of faecal strep from the result of sample analyzed in Baptist Church (43), ECWA (115), Chief Palace/Market (3), Angwa Hausa (5) 
and Point Clime Sachet (19). Meanwhile, Mpape has no record of Faecal Strep. Thus, major factors affecting microbiological quality of ground waters are discharges from sewage works and runoff from informal settlements. Indicator organisms are commonly used to assess the microbiological quality of surface waters and faecal coliforms (FC), which are the most commonly used bacterial indicator of faecal pollution $[13,77]$. They are found in water that is contaminated with faecal wastes of human and animal origin. Total coliforms (TC) comprise bacterial species of faecal origin as well as other bacterial groups (e.g., bacteria commonly occurring in soil). The coliforms are indicative of the general hygienic quality of the water and potential risk of infectious diseases from water. High FC and TC counts in water are usually manifested in the form of diarrhoea and sometimes by fever and other secondary complications. Bathing and swimming in streams and river are also common among children and adults in Piwoyi community. The probability of ingesting infective dose of disease-causing microorganism is very high considering the fact that water borne pathogens generally have low infective dose.

\section{Conclusion}

In conclusion, heavy metals are a very important class of carcinogens. Owing to the nature of modern life, we are all constantly exposed to carcinogenic metals through the environment. This makes defining mechanism a very significant task. However, metals are probably the least studied of any major class of human carcinogens and, on this basis alone, deserve additional effort. Additionally, human metal exposures are invariably of a complex nature, including erratic rates of exposure and/or differing periods of exposure. The nature of metal exposure often changes with time and the advent of new technologies and different industrial applications. Thus, the results of findings on assessing the sources and quality of drinking water in Piwoyi community of Federal Capital Territory, Abuja, Nigeria reveals that the sources of water so identified have high microbial parameters as such can pose significant health threat to the people of Piwoyi Community and other visitors who drink from the source of their water. In addition, high level of some physicochemical parameters so examine can pose significant health risk as well. Therefore, the water is considered to be unsafe for drinking. Thus, this study summarized the objectives of study as:

1. Physicochemical qualities: The results of analysis shows that the Electrical conductivity in the water samples are within the desirable standard (1000) except Chief Palace/Market with high conductivity (1027). Temperature of water samples were within the permissible limits $\left(30^{\circ} \mathrm{C}\right)$. $\mathrm{pH}$ level in water samples are within the desirable standard except Baptist Church and Chief palace/Market with lower $\mathrm{pH}$ (Acidity). Turbidity of the water samples are within desirable limit in Mpape and Baptist Church, but higher in other areas. Total Dissolve Solid is higher in Baptist Church and Chief Palace/Market and within the acceptable limit in other identified water sources. Dissolve oxygen is within the acceptable limit in ECWA but higher in other identified sources. Chloride is within the permissible level. Total hardness is higher virtually in all the boreholes sampled but within the permissible level in sachet water. Alkalinity of water sampled is within the permissible level in Baptist Church, Chief Palace/Market and Sachet Water but higher in other identified sources. Nitrate is higher in Baptist Church and Chief Palace/Market but within the permissible level in other sources. Study also reveals high level of calcium in Baptist Church, ECWA, Chief palace/Market and Angwa Hausa; and within the permissible level in other sources. Magnesium is higher in Baptist Church, ECWA, Chief Palace/Market and Angwa Hausa; while others are within the permissible level of water quality. Phosphate, phosphorous, copper, zinc, iron, fluoride, sodium, potassium, are within the desirable standard of Water Quality Nigeria.

2. Microbiological quality: the study reveals evidence of faecal contamination, E-coli and Faecal Strep as such render the water unsafe for drinking. 


\section{Recommendation}

The finite resource of water is fundamental to the well-being of human life, as water and sanitation are deemed to be a human right, development partners [58] and government funds should rightly continue to support improvements in WASH access for the billions of people who remain underserved $[4,5,7,8,9,11,12,13]$. While, engaging in the process of strengthening societies and ecosystems to ensure the stability, equitability and productivity $[20,31]$. Water quantity, quality and availability are changing according to the drivers such as population densification, changes in land-use systems [18, 24, 33], climatic conditions variations $[20,52,56]$, worldwide poverty $[13,51]$ and selections of energy sources $[78,79]$. Thus, this current study's predictions therefore suggest several potentially effective strategies for risk mitigation as follows:

1. There is urgent need for environmental education and aggressive sensitization of Piwoyi residents on the consumption of polluted water, Water Sanitation and Hygiene, as all SDGs are interlinked in the context of water being essential component of life. From alleviating poverty to form partnerships. SDGs are well versed in sustainable water use, and industries have the opportunity to make their production more sustainable by aligning with them. Thus, there is need for the provision of alternative drinking water and protein source.

2. There is need for government to enhance public private infrastructure partnership on provision of potable water in the community and the promulgation and enforcement of host community protection policies and laws.

3. Residents of Piwoyi community should be advised to go for medical check-up so that appropriate treatment can be given to prevent future health challenges.

4. There is need for proper sewage management and designs of sewage disposal around the community in line with relevant regulations and policies.

5. There is also need to avoid indiscriminate discharge of waste water on public places.

6. Routine purification of drinking water through necessary domestic purification process should be adopted.

7. Federal Ministry of Water Resources should ensure routine water quality analysis in all communities to enhance public health and prevention of diseases or health problems that may hinder life expectancy. This will enhance the prevention of water borne diseases and water pollution.

8. Further studies on the level of open defecation in the area will go a long towards water sanitation and hygiene (WASH).

Availability of data and materials: Not applicable.

Ethics approval: Not applicable.

Consent to participate: The authors declare their consent to participate in this article.

Consent for publication: The authors declare their consent to publish this article.

Conflict of interest: The authors declare no competing interests.

Author's contributions: Afolabi Abiodun Segun: Investigation, Data curation, Resources, Conceptualization, Methodology Writing, original draft. Raimi Morufu Olalekan: Supervision, literature searching, writing, review \& editing. 


\section{References}

[1] Morufu Raimi and Clinton Ezekwe (2017), Assessment of Trace Elements in Surface and Ground Water Quality (2017) LAP Lambert Academic Publishing. Mauritius. ISBN: 978-3-659-38813-2. www.omniscriptum.com.

[2] Raimi, M. O, Pigha, Tarilayun K and Ochayi, E. O (2017) Water-Related Problems and Health Conditions in the Oil Producing Communities in Central Senatorial District of Bayelsa State. Imperial Journal of Interdisciplinary Research (IJIR) Vol-3, Issue-6, ISSN: 2454-1362.

[3] Raimi Morufu Olalekan and Sabinus Chibuzor Ezugwu (2017) An Assessment of Trace Elements in Surface and Ground Water Quality in the Ebocha-Obrikom Oil and Gas Producing Area of Rivers State, Nigeria. International Journal for Scientific and Engineering Research (Ijser): Volume 8, Issue 6, July Edition. ISSN: 2229-5518.

[4] Olalekan, R. M., Omidiji, A. O., Nimisngha, D., Odipe, O. E. and Olalekan, A. S. (2018). Health Risk Assessment on Heavy Metals Ingestion through Groundwater Drinking Pathway for Residents in an Oil and Gas Producing Area of Rivers State, Nigeria. Open Journal of Yangtze Gas and Oil, 3, 191-206. https://doi.org/10.4236/ojogas.2018.33017.

[5] Olalekan R. M, Vivien O. T, Adedoyin O. O, et al. (2018). The sources of water supply, sanitation facilities and hygiene practices in oil producing communities in central senatorial district of Bayelsa state, Nigeria. MOJ Public Health. 2018;7(6):337-345. DOI: 10.15406/mojph.2018.07.00265.

[6] Henry O. Sawyerr, Odipe E. Oluwaseun1, Olawale S. Asabi, Raimi M. Olalekan (2019) Bacteriological Assessment of Selected Hand Dug Wells in Students' Residential Area: A Case Study of Osun State College of Health Technology, Ilesa, Nigeria. Global Scientific Journal, Volume 7, Issue 1, January 2019, Online: ISSN 2320-9186. www.globalscientificjournal.com.

[7] Raimi M. O, Abdulraheem A. F, Major Iteimowei, Odipe O. E, Isa H. M, Onyeche Chinwendu (2019). The Sources of Water Supply, Sanitation Facilities and Hygiene Practices in an Island Community: Amassoma, Bayelsa State, Nigeria. Public Health Open Access 2019, 3(1): 000134. ISSN: 2578-5001. DOI: 10.23880/phoa-16000134.

[8] Olalekan RM, Adedoyin OO, Ayibatonbira A, et al (2019). "Digging deeper" evidence on water crisis and its solution in Nigeria for Bayelsa state: a study of current scenario. International Journal of Hydrology. 2019;3(4):244-257. DOI: 10.15406/ijh.2019.03.00187.

[9] Raimi Morufu Olalekan, Omidiji Adedoyin O, Adeolu Timothy Adedotun, Odipe Oluwaseun Emmanuel and Babatunde Anu (2019) An Analysis of Bayelsa State Water Challenges on the Rise and Its Possible Solutions. Acta Scientific Agriculture 3.8 (2019): 110-125. DOI: 10.31080/ASAG.2019.03.0572.

[10] Raimi Morufu Olalekan (2019) $21^{\text {st }}$ Century Emerging Issues in Pollution Control. $6^{\text {th }}$ Global Summit and Expo on Pollution Control May 06-07, 2019 Amsterdam, Netherlands.

[11] Gift RA, Olalekan RM, Owobi OE, Oluwakemi RM, Anu B, Funmilayo AA (2020). Nigerians crying for availability of electricity and water: a key driver to life coping measures for deepening stay at home inclusion to slow covid-19 spread. Open Access Journal of Science. 2020;4(3):69-80. DOI: 10.15406/oajs.2020.04.00155.

[12] Gift R A, Olalekan RM (2020). Access to electricity and water in Nigeria: a panacea to slow the spread of Covid-19. Open Access J Sci. 2020;4(2):34. DOI: 10.15406/oajs.2020.04.00148. https://medcrave.com/index.php?/articles/det/21409/

[13] Olalekan R. M, Dodeye E. O, Efegbere H. A, Odipe O. E. Deinkuro N. S, Babatunde A and Ochayi E. O (2020) Leaving No One Behind? Drinking-Water Challenge on the Rise in Niger Delta Region of Nigeria: A Review. Merit Research Journal of Environmental Science and Toxicology (ISSN: 2350-2266) Vol. 6(1): 031-049 DOI: 10.5281/zenodo.3779288.

[14] Rajiv Shah Dr. (2011), Water Sanitation and Hygiene. World Water Day, 2011.

[15] Agwu A.1, Avoaja A. G., and Kalu A. U (2013), The Assessment of Drinking Water Sources in Aba Metropolis, Abia State, Nigeria. Resources and Environment 2013, 3(4): 72-76 doi: 10.5923/J.Re.20130304.02.

[16] Afolabi T. A, Ogbuneke C. C., Ogunkunle O. A. and Bamiro F. O. (2012), Comparative Assessment of the Potable Quality of Water from Industrial, Urban and Rural Parts of Lagos, Nigeria. Ife Journal of Science vol.14, no. 2 (2012).

[17] Premoboere Edna Ateboh and Raimi Morufu Olalekan (2018). Corporate Civil Liability and Compensation Regime for Environmental Pollution in the Niger Delta. International Journal of Recent Advances in Multidisciplinary Research Vol. 05, Issue 06, pp. 38703893, June, 2018.

[18] Suleiman Romoke Monsurat, Raimi Morufu Olalekan and Sawyerr Henry Olawale (2019) A Deep Dive into the Review of National Environmental Standards and Regulations Enforcement Agency (NESREA) Act. International Research Journal of Applied Sciences. pISSN: 2663-5577, eISSN: 2663-5585. DOI No. Irjas.2019.123.123. www.scirange.com. https://scirange.com/abstract/irjas.2019.108.125.

[19] Deinkuro Nimisngha Sanchez, Charles W. Knapp, Raimi Morufu Olalekan, Nimlang Henry Nanalok (2021) Oil Spills in the Niger Delta Region, Nigeria: Environmental Fate of Toxic Volatile Organics. 28 June 2021, PREPRINT (Version 1) available at Research Square. DOI: https://doi.org/10.21203/rs.3.rs-654453/v1.

[20] Raimi Morufu Olalekan, Abiola Ilesanmi, Ogah Alima, Dodeye E. Omini and Aziba-anyam Gift Raimi (2021) Exploring How Human Activities Disturb the Balance of Biogeochemical Cycles: Evidence from the Carbon, Nitrogen and Hydrologic Cycles. IntechOpen. DOI: http://dx.doi.org/10.5772/intechopen.98533. https://www.intechopen.com/online-first/77696.

[21] Bichi, M. H. and Amatobi, D. A. (2013), Assessment of the Quality of Water Supplied by Water Vendors to Households in SabonGari Area of Kano, Northern Nigeria. The International Journal of Engineering and Science (Ijes), 2(7):09-17. 
[22] Odipe O. E, Raimi M. O, Suleiman F (2018). Assessment of Heavy Metals in Effluent Water Discharges from Textile Industry and River Water at Close Proximity: A Comparison of Two Textile Industries from Funtua and Zaria, North Western Nigeria. Madridge Journal of Agriculture and Environmental Sciences. 2018; 1(1): 1-6.doi: 10.18689/mjaes-1000101. https://madridge.org/journal-of-agriculture-and-environmental-sciences/mjaes-1000101.php

[23] Raimi M. O, Omidiji A. O, Adio Z. O (2019) Health Impact Assessment: A Tool to Advance the Knowledge of Policy Makers Understand Sustainable Development Goals. Conference paper presented at the: Association for Environmental Impact Assessment of Nigeria (AEIAN) On Impact Assessment: A Tool for Achieving the Sustainable Development Goals in Nigeria, 7th and 8th November, 2019 in University of Port Harcourt. DOI: 10.13140/RG.2.2.35999.51366 https://www.researchgate.net/publication/337146101.

[24] Raimi Morufu Olalekan, Bilewu Olaolu Oyinlola, Adio Zulkarnaini Olalekan, Abdulrahman Halimat (2019) Women Contributions to Sustainable Environments in Nigeria. Journal of Scientific Research in Allied Sciences. 5(4), 35-51. ISSN NO. 2455-5800. DOI No. 10.26838/JUSRES.2019.5.4.104.

[25] Omidiji A. O and Raimi M. O (2019) Practitioners Perspective of Environmental, Social and Health Impact Assessment (ESHIA) Practice in Nigeria: A Vital Instrument for Sustainable Development. Paper Presented at the Association for Environmental Impact Assessment of Nigeria (AEIAN) On Impact Assessment: A Tool for Achieving the Sustainable Development Goals in Nigeria, 7th and 8th November, 2019 In University of Port Harcourt. https://aeian.org/wp-content/uploads/2019/08/EIA-Presentations-Portharcourt.pdf.

[26] Olalekan R. M, Oluwatoyin O and Olalekan A (2020) Health Impact Assessment: A tool to Advance the Knowledge of Policy Makers Understand Sustainable Development Goals: A Review. ES Journal of Public Health; 1(1); 1002. https://escientificlibrary.com/public-health/in-press.php.

[27] Adedoyin OO, Olalekan RM, Olawale SH, et al (2020). A review of environmental, social and health impact assessment (Eshia) practice in Nigeria: a panacea for sustainable development and decision making. MOJ Public Health. 2020;9(3):81-87. DOI: 10.15406/mojph.2020.09.00328. https://medcraveonline.com/MOJPH/MOJPH-09-00328.pdf.

[28] Olalekan RM, Oluwatoyin OA, Olawale SH, Emmanuel OO, Olalekan AZ (2020) A Critical Review of Health Impact Assessment: Towards Strengthening the Knowledge of Decision Makers Understand Sustainable Development Goals in the Twenty-First Century: Necessity Today; Essentiality Tomorrow. Research and Advances: Environmental Sciences. 2020(1): 72-84. DOI: 10.33513/RAES/2001-13. https://ospopac.com/journal/environmental-sciences/early-online.

[29] Raimi Morufu Olalekan, Ihuoma Blossom Adindu, Esther Onyinyechi Udensin, Abdulraheem Aishat Funmilayo, Opufou Tarekebi, Deinkuro Nimisingha Sanchez, Adebayo Patrick Adekunle and Adeniji Anthony Olusola (2020) “Health Impact Assessment: Expanding Public Policy Tools for Promoting Sustainable Development Goals (SDGs) in Nigeria". EC Emergency Medicine and Critical Care 4.9 (2020).

[30] UNESCO-IHP (2014), Water In The Post-2015 Development Agenda and Sustainable Development Goals. Paris, France 2014.

[31] Okoyen E, Raimi M O, Omidiji A O, Ebuete A W (2020). Governing the Environmental Impact of Dredging: Consequences for Marine Biodiversity in the Niger Delta Region of Nigeria. Insights Mining Science and technology 2020; 2(3): 555586. DOI: 10.19080/IMST.2020.02.555586. https://juniperpublishers.com/imst/pdf/IMST.MS.ID.555586.pdf.

[32] Oluwaseun Emmanuel Odipe., Raimi Morufu Olalekan, Nimisingha Deinkuro Sanchez, Abdulraheem Aishat Funmilayo, Okolosi-Patainnocent Edewor, Habeeb Modupe Lateefat and Mary Fadeyibi (2019) Assessment of Environmental Sanitation, Food Safety Knowledge, Handling Practice among Food Handlers of Bukateria Complexes in Iju Town, Akure North of Ondo-State, Nigeria. Acta Scientific Nutritional Health 3.6 (2019): 186-200. DOI: 10.31080/ASNH.2019.03.0308

[33] Nova Scotia Environment and Labour (2008), Drinking Water Quality and Treatment. Nova Scotia, Canada.

[34] Raimi M O, Suleiman R M, Odipe O E, Salami J T, Oshatunberu M, et al (2019). Women Role in Environmental Conservation and Development in Nigeria. Ecology \& Conservation Science; 1(2): DOI: 10.19080/ECOA.2019.01.555558. Volume 1 Issue 2 - July 2019. https://juniperpublishers.com/ecoa/pdf/ECOA.MS.ID.555558.pdf

[35] Robert Bos, David Alves, Carolina Latorre, Neil Macleod, Gerard Payen, Virginia Roaf and Michael Rouse (2016), Manual of the Human Rights to Safe Drinking Water and Sanitation for Practitioners. IWA Publishing, Alliance House, London, UK.

[36] World Health Organization and UNICEF (2006) Meeting the MDG Drinking Water and Sanitation Target: the Urban and Rural Challenge of the Decade. www.un.org/sustainabledevelopment.

[37] Jain R. K and Sunil S. Rao (2011), Industrial Safety, Health and Environment Management Systems. Khanna Publishers. ISBN: 97881-7409-210-2.

[38] Sadiya Atiku, Chukwuma C. Ogbaga, Olatunbosun O. Alonge, and Onyinye F. Nwagbara (2017), Comparative Study on the Physicochemical and Bacteriological Quality of Some Drinking Water Sources in Abuja, Nigeria. www.preprints.org.

[39] Water Aid (2007) Meeting the MDG of Water Supply and Sanitation Target in Nigeria: Can Local Governments achieve it. Study Report Submitted to Water Aid, Abuja, Nigeria, 2007. www.wateraid.org/nigeria.

[40] WHO (2011) Guidelines for Drinking-Water Quality, Fourth Edition?

[41] Grady Caitlin A., Shih-Chi Weng, and Ernest R. Blatchley III (2014), Global Potable Water: Current Status, Critical Problems, and Future Perspectives. 
[42] Isah, H. M., Sawyerr, H. O., Raimi, M. O., Bashir, B. G., Haladu, S. \& Odipe, O. E. (2020). Assessment of Commonly Used Pesticides and Frequency of Self-Reported Symptoms on Farmers Health in Kura, Kano State, Nigeria. Journal of Education and Learning Management (JELM), HolyKnight, vol. 1, 31-54. doi.org/10.46410/jelm.2020.1.1.05. https://holyknight.co.uk/journals/jelm-articles/.

[43] Isah Hussain Muhammad, Raimi Morufu Olalekan, Sawyerr Henry Olawale, Odipe Oluwaseun Emmanuel, Bashir Bala Getso, Suleiman Haladu (2020) Qualitative Adverse Health Experience Associated with Pesticides Usage among Farmers from Kura, Kano State, Nigeria. Merit Research Journal of Medicine and Medical Sciences (ISSN: 2354-323X) Vol. 8(8) pp. 432-447, August, 2020. DOI: 10.5281/zenodo.4008682. https://meritresearchjournals.org/mms/content/2020/August/Isah\%20et\%20al.htm.

[44] Olalekan RM, Muhammad IH, Okoronkwo UL, Akopjubaro EH (2020). Assessment of safety practices and farmer's behaviors adopted when handling pesticides in rural Kano state, Nigeria. Arts \& Humanities Open Access Journal. 2020;4(5):191-201. DOI: 10.15406/ahoaj.2020.04.00170.

[45] Morufu Olalekan Raimi (2021). "Self-reported Symptoms on Farmers Health and Commonly Used Pesticides Related to Exposure in Kura, Kano State, Nigeria". Annals of Community Medicine \& Public Health. 1(1): 1002. http://www.remedypublications.com/open-access/self-reported-symptoms-on-farmers-health-and-commonly-used-pesticides-related-6595.pdf. http://www.remedypublications.com/annals-of-community-medicine-public-health-home.php.

[46] Hussain Muhammad Isah, Morufu Olalekan Raimi, Henry Olawale Sawyerr (2021) Patterns of Chemical Pesticide Use and Determinants of Self-Reported Symptoms on Farmers Health: A Case Study in Kano State for Kura Local Government Area of Nigeria. Research on World Agricultural Economy. Vol 2, No. 1. DOI: http://dx.doi.org/10.36956/rwae.v2i1.342. http://ojs.nassg.org/index.php/rwae/issue/view/31

[47] Hussain Muhammad Isah, Morufu Olalekan Raimi, Henry Olawale Sawyerr (2021) Probabilistic Assessment of Self-Reported Symptoms on Farmers Health: A Case Study in Kano State for Kura Local Government Area of Nigeria. Research on World Agricultural Economy. Vol 2, No. 1. DOI: http://dx.doi.org/10.36956/rwae.v2i1.336. http://ojs.nassg.org/index.php/rwaecn/article/view/336/pdf.

[48] Morufu Olalekan Raimi, Tonye Vivien Odubo, Ogah Alima, Henry Akpojubaro Efegbere, Abinotami Williams Ebuete (2021) Articulating the effect of Pesticides Use and Sustainable Development Goals (SDGs): The Science of Improving Lives through Decision Impacts. Research on World Agricultural Economy. Vol 2, No. 1. DOI: http://dx.doi.org/10.36956/rwae.v2i1.347.http://ojs.nas g.org/index.php/rwae/is sue/view/31

[49] Akina Shrestha, Subodh Sharma, Jana Gerold, Severine Erismann, Sanjay Sagar, Rajendra Koju, Christian Schindler, Peter Odermatt, Jurg Utzinger and Gueladio Cisse (2017), Water Quality, Sanitation, and Hygiene Conditions in Schools and Households in Dolakha and Ramechhap Districts, Nepal: Results from A Cross Sectional Survey. International Journal of Environmental Research and Public Health, 2017, 14, 89; doi:10.3390/ijerph14010089. www.mdpi.com/journal/ijerph.

[50] Federal Republic of Nigeria (2000), Water Supply and Sanitation Interim Strategy Note. November, 2000.

[51] Morufu Olalekan Raimi, Ebikapaye Okoyen, Tuebi Moses, Aziba-anyam Gift Raimi, Adedoyin Oluwatoyin Omidiji, Aishat Funmilayo Abdulraheem, Mariam Oluwakemi Raimi, Beatrice Oka Joseph (2021) Do Weak Institutions Prolong Crises? [\#ENDSARs] in the Light of the Challenges and opportunities beyond COVID-19 Pandemic and the Next Normal in Nigeria. Communication, Society and Media. ISSN 2576-5388 (Print) ISSN 2576-5396 (Online) Vol. 4, No. 2, DOI: https://doi.org/10.22158/csm.v4n2p1. http://www.scholink.org/ojs/index.php/csm/article/view/3790.

[52] Morufu Olalekan Raimi, Tonye Vivien Odubo \& Adedoyin Oluwatoyin Omidiji (2021) Creating the Healthiest Nation: Climate Change and Environmental Health Impacts in Nigeria: A Narrative Review. Scholink Sustainability in Environment. ISSN 2470637X (Print) ISSN 2470-6388 (Online) Vol. 6, No. 1, 2021 www.scholink.org/ojs/index.php/se. URL: http://dx.doi.org/10.22158/se.v6n1p61. http://www.scholink.org/ojs/index.php/se/article/view/3684.

[53] WHO/UNICEF (2008) A Snapshot of Drinking Water in Africa.

[54] UN-Water, WHO and UNICEF (2016), Goal 6: Ensure Availability and Sustainable Management of Water and Sanitation for All.

[55] World Health Organization (WHO) and United Nations Department of Economic and Social Affairs (2014), International Decade for Action 'Water for Life' 2005-2015).

[56] Raimi Morufu Olalekan, Tonye V. Odubo, Omidiji Adedoyin O, Oluwaseun E. Odipe (2018) Environmental Health and Climate Change in Nigeria. World Congress on Global Warming. Valencia, Spain. December 06-07, 2018.

[57] Raimi Morufu Olalekan, Ayinla Lateefat Olajumoke, Ogah Alima (2021) First to Respond, Last to Leave: The Role of Para-Military Agencies in Disaster Management: Evidence from Nigeria. Sumerianz Journal of Medical and Healthcare, 2021, Vol. 4, No. 2, pp. 96-100 ISSN(e): 2663-421X, ISSN(p): 2706-8404 Website: https://www.sumerianz.com DOI: https://doi.org/10.47752/sjmh.42.96.100. https:/www.sumerianz.com/?ic=journal-home\&journal=31\&info=archive-detail\&month $=06-2021 \&$ issue $=2 \&$ volume $=4$

[58] Olalekan RM, Omidiji AO, Williams EA, Christianah MB, Modupe O (2019). The roles of all tiers of government and development partners in environmental conservation of natural resource: a case study in Nigeria. MOJ Ecology E Environmental Sciences 2019;4(3):114-121. DOI: 10.15406/mojes.2019.04.00142.

[59] https://en.m.wikipedia.org/wiki/Abuja.

[60] APHA (2005), Standard Methods for Examination of Water and Waste Water. American Public Health Association, Water Environment Federation Publication, Washington DC. 
[61] Karunanidhi, D.; Aravinthasamy, P.; Deepali, M.; Subramani, T.; Bellows, B.C.; Li, P (2020). Groundwater quality evolution based on geochemical modeling and aptness testing for ingestion using entropy water quality and total hazard indexes in an urbanindustrial area (Tiruppur) of Southern India. Environ. Sci. Pollut. Res. 1-1.

[62] He, X.; Li, P.; Ji, Y.; Wang, Y.; Su, Z.; Elumalai, V (2020). Groundwater Arsenic and Fluoride and Associated Arsenicosis and Fluorosis in China: Occurrence, Distribution and Management. Expo. Health 2020, 12, 355-368.

[63] Raimi Morufu Olalekan, Omidiji Adedoyin O, Odipe Oluwaseun Emmanuel, Suleiman Hajarat Ohunene (2019) Open Defecation and Public Toilets Importance: An Economic Perspective. Preventing Health Care in Nigeria: Everyone, Everywhere Leaving Nobody Behind. July 29 - August 1, 2019 National Open University Auditorium, University Village, Jabi Abuja.

[64] Adimallaa, N., \& Qian, H. (2019a). Groundwater quality evaluation using water quality index (WQI) for drinking purposes and human health risk (HHR) assessment in an agricultural region of Nanganur, south India. Ecotoxicology and Environmental Safety, 176, 153-161.

[65] WHO (2017) Guidelines for drinking-water quality, fourth edition incorporating the first addendum. https://www.who.int/water_sanitation_health/publications/ drinking-water-quality-guidelines-4-including-1st-addendum/en/ [accessed 29 June 2020].

[66] Li, P., He, S., Yang, N., Xiang, G., et al. (2018a). Groundwater quality assessment for domestic and agricultural purposes in Yan'an City, northwest China: Implications to sustainable groundwater quality management on the Loess Plateau. Environmental Earth Sciences, 77(23), 775. https:// doi.org/10.1007/s12665-2018-7968-3.

[67] WHO (2010) Preventing disease through healthy environments: Exposure to lead: A major public health concern. WHO Document Production Services, Geneva, Switzerland

[68] USEPA. (2011). Exposure Factors Handbook: 2011 edition. EPA 600/R-090/052F. Washington, DC: United States Environmental Protection Agency, Office of Research and Development. https://cfpub.epa.gov/ncea/risk/recordisplay.cfm? deid=236252 [accessed 29 June 2020].

[69] Valko Mmhcm, Morris H, Cronin Mtd. (2005). Metals, Toxicity and Oxidative Stress. Curr Med Chem 12(10): 1161-1208.

[70] Vuori K-M. (1995). Direct and Indirect Effects of Iron on River Eco Systems. Annal Zoo Fennici 32: 317-329.

[71] Phippen B, Horvath C, Nordin R, Nagpal N. (2008). Ambient Water Quality Guidelines for Iron: Overview. Ministry of Environment Province of British Columbia.

[72] Albretsen J. (2006). The Toxicity of Iron, An Essential Element. Veterinary Medicine 82-90.

[73] EFSA. (2012a). Cadmium dietary exposure in the European population. Scientific report of EFSA. EFSA Journal 2012;10:2551.

[74] Henry Olawale Sawyerr, Morufu Olalekan Raimi, Adedotun Timothy Adeolu \& Oluwaseun Emmanuel Odipe (2019) Measures of Harm from Heavy Metal Pollution in Battery Technicians' Workshop within Ilorin Metropolis, Kwara State, Nigeria. Scholink Communication, Society and Media ISSN 2576-5388 (Print) ISSN 2576-5396 (Online) Vol. 2, No. 2, 2019 www.scholink.org/ojs/index.php/csm. DOI: https://doi.org/10.22158/csm.v2n2p73.

[75] Rajurkar, N. S.; Nongbri, B.; Patwardhan, A. M (2003). Physico-Chemical and Microbial Analysis of Umian (Brapani) Lake Water. Indian Journal of Environmental Proceedings, V. 23, N. 6, P. 633- 639.

[76] Radha Krishnan, R.; Dharmaraj, K.; Ranjitha Kumari, B. D (2007). A Comparative Study on the Physicochemical and Bacterial Analysis of Drinking, Borewell and Sewage Water in the Three Different Places of Sivakasi. Journal of Environmental Biology, V. 28, N. 1, P. 105-108, 2007.

[77] South Africa (1998). Department of Water Affairs and Forestry. Water Research Commission. Quality of Domestic Water Supplies: Volume 1: Assessment Guide. 2. Ed. Pretoria, 1998.

[78] Ebuete Abinotami Williams, Raimi Morufu Olalekan, Ebuete Ibim Yarwamara \& Oshatunberu Modupe (2019) Renewable Energy Sources for the Present and Future: An Alternative Power Supply for Nigeria. Energy and Earth Science. Vol. 2, No. 2, 2019. URL: http://dx.doi.org/10.22158/ees.v2n2p18. http://www.scholink.org/ojs/index.php/ees/article/view/2124.

[79] Ajayi Folajimi Ajibola, Raimi Morufu Olalekan, Steve-Awogbami Oluseyi Catherine, Adeniji Anthony Olusola, Adebayo Patrick Adekunle (2020) Policy Responses to Addressing the Issues of Environmental Health Impacts of Charcoal Factory in Nigeria: Necessity Today; Essentiality Tomorrow. Communication, Society and Media. Vol 3, No $3 . \quad$ DOI: https://doi.org/10.22158/csm.v3n3p1. http://www.scholink.org/ojs/index.php/csm/article/view/2940. 